\title{
Tranexamic acid for treatment and prophylaxis of bleeding and hyperfibrinolysis
}

\author{
Ingrid Pabinger · Dietmar Fries · Herbert Schöchl · Werner Streif · Wolfgang Toller
}

Received: 29 February 2016 / Accepted: 14 March 2017 / Published online: 21 April 2017

(C) The Author(s) 2017. This article is an open access publication.

Summary Uncontrolled massive bleeding with subsequent derangement of the coagulation system is a major challenge in the management of both surgical and seriously injured patients. Under physiological conditions activators and inhibitors of coagulation regulate the sensitive balance between clot formation and fibrinolysis. In some cases, excessive and diffuse bleeding is caused by systemic activation of fibrinolysis, i. e. hyperfibrinolysis (HF). Uncontrolled HF is associated with a high mortality. Polytrauma patients and those undergoing surgical procedures involving organs rich in plasminogen proactivators (e.g. liver, kidney, pancreas, uterus and prostate gland) are at a high risk for HF. Antifibrinolytics, such as tranexamic acid (TXA) are used for prophylaxis and treatment of bleeding caused by a local or generalized $\mathrm{HF}$ as well as other hemorrhagic conditions. TXA is a synthetic lysine analogue that has been available in Austria since

Univ.Prof. Dr. I. Pabinger $(\bowtie)$

Clinical Department of Hematology and Hemostaseology,

Medical University Vienna, Vienna, Austria

ingrid.pabinger@meduniwien.ac.at

\section{Fries}

Department of General and Surgical Intensive Care

Medicine, Medical University Innsbruck, Innsbruck, Austria

\section{H. Schöchl}

Department of Anesthesiology and Intensive Care Medicine, AUVA Accident Hospital Salzburg, Salzburg, Austria

Academic Teaching Hospital, Paracelsus Private Medical University Salzburg, Salzburg, Austria

\section{W. Streif}

Department of Children and Adolescents Medicine, Medical University Innsbruck, Innsbruck, Austria

\section{W. Toller}

Department of Anesthesiology and Intensive Care Medicine, Medical University Graz, Graz, Austria
1966. TXA is of utmost importance in the prevention and treatment of traumatic and perioperative bleeding due to the resulting reduction in perioperative blood loss and blood transfusion requirements. The following article presents the different fields of application of TXA with particular respect to indications and dosages, based on a literature search and on current guidelines.

Keywords Trauma - Surgery · Bleeding - Hyperfibrinolysis · Tranexamic acid

\section{Introduction}

Massive bleeding after surgical interventions or severe trauma continues to be one of the most frequent life-threatening emergencies [1-3]. Trauma-associated hemorrhagic shock is the most frequent cause of avoidable deaths, with hyperfibrinolysis (HF) at the time of hospitalization having been identified as an independent predictor of mortality [4-6]. In addition, peripartum bleeding, with a proportion of up to $25 \%$ of pregnancy-associated complications, ranks first along with thromboembolism, among the causes of maternal death [7].

Hemostatic disorders in the context of massive bleeding have long been deemed as coagulopathies resulting from blood loss, dilution and consumption, forming the "lethal triad" along with hypothermia and acidosis. More recent studies have shown, however, that shock and the resulting hypoperfusion may trigger coagulopathy independently of tissue trauma, with HF being regarded as the underlying mechanism [8].

Since the 1960s the non-specific serine protease inhibitor aprotinin and the inhibitors of plasminogen activation tranexamic acid (TXA) and/or $\varepsilon$-aminocapronic acid (EAXA) have been used in the treat- 
ment of HF. Aprotinin was, however, withdrawn from the market in 2007, since massive side effects had been observed in the course of complex cardiovascular surgery [9]. First described some 50 years ago, TXA has been widely used for the prevention and therapy of hemorrhages and/or primary and secondary HF. In recent years interest has increasingly focused on intravenous administration, since it has been shown that early administration of TXA after severe trauma can significantly increase the rate of survival [10-13]. Accordingly, in 2011 the World Health Organization (WHO) added TXA to its list of essential medicines. ${ }^{1}$ In addition, the reduction of perioperative blood loss and the resulting decline in the demand for transfusions have induced European societies (Task Force for Advanced Bleeding Care in Trauma and the European Society of Anesthesiology) to publish in recent guidelines a $1 \mathrm{~A}$ recommendation for the use of TXA in the case of traumatic and perioperative bleeding [2, 3].

This article presents the different fields of application of TXA, including those outside anesthesia and intensive care medicine, on the basis of current studies and guideline recommendations regarding indications and dosage schedules.

\section{Hyperfibrinolysis}

\section{Pathophysiology}

By definition, HF is a state of increased clot resolution that may be associated with severe, potentially life-threatening hemorrhage. It may be caused by excessive plasmin formation or a reduction of plasmin decomposition due to a depletion of $\alpha_{2}$-antiplasmin. Plasmin is capable of cleaving both fibrin and fibrinogen. The resulting fibrin cleavage products, which inhibit the cross-linking of fibrin, can aggravate this effect [14].

\section{Disorders associated with HF}

Clinical studies have shown that a number of pathological conditions may go hand in hand with the activation of the fibrinolytic system. In recent years the focus has increasingly been on severe trauma with subsequent tissue hypoxia. HF has also been observed in the context of severe postpartum hemorrhage [15]. Furthermore, an increase in the activation of fibrinolysis has been reported in the course of extracorporeal circulation and in the case of liver transplantations [16-18].

\footnotetext{
1 http://www.who.int/selection_medicines/committees/expert/ 18/applications/tranexamic/en/.
}

\section{Diagnosis}

Diagnosing HF often proves difficult, since no specific tests that would allow prompt therapeutic decisions are currently available. Tests such as the determination of plasmin-antiplasmin complexes or $\alpha_{2}$-antiplasmin assays are time-consuming and hardly practicable in everyday clinical work. The same holds for the euglobulin lysis time, long seen as the gold standard but both time-consuming and fault-prone [19]. Viscoelastic tests such as thromboelastometry or thrombelastography (ROTEM and TEG, respectively), on the other hand, can detect HF but only if plasminantiplasmin levels are high or $\alpha_{2}$-antiplasmin levels are very low [20]. There is an urgent need for better and more sensitive diagnostic analyses and rapid HF monitoring to facilitate differentiation between hyperfibrinolytic states and other coagulopathies [21]. Moreover, it would be important to be able to identify patients who could be treated with TXA, since recent data suggest that not all patients benefit from TXA therapy $[22,23]$.

\section{Mode of action of tranexamic acid}

TXA is a synthetic lysine analogue that inhibits conversion of plasminogen to plasmin by preventing plasminogen from binding to the fibrin molecule. TXA also inhibits plasmin activity directly, although only at higher doses [24]. TXA inhibits fibrin cleavage, thus reducing the risk of hemorrhage. It also blocks binding of $\alpha_{2}$-antiplasmin and inhibits inflammatory reactions. Compared with epsilon-aminocaproic acid (EACA), TXA is more potent by a factor of 10 [25]. The substance can be administered orally or intravenously (Table 1), its oral bioavailability ranging from $30-50 \%$. With a plasma protein binding of $3 \%$ it can completely cross the placenta. Metabolism of TXA in the liver is low, renal clearance amounts to $95 \%$ [26], and the halflife in adults is approximately $2.3 \mathrm{~h} \mathrm{[27].}$

So far there have been no reports suggesting the presence of serious side effects, not even with high dosages and long-term administration (Table 2; [28]). Since renal insufficiency carries the risk of accumulation of TXA, administration of TXA is contraindicated in patients with severe kidney dysfunction (Table 3). Dosages need not be modified in patients with impaired liver function and elderly patients with no kidney dysfunction (Table 4). In patients with slight to moderate kidney dysfunction TXA dosages should be reduced in dependence on serum creatinine levels (for details see SmPC Cyklokapron $\left.{ }^{\circledR}[27]\right)$.

\section{Tranexamic acid in acute hemorrhagic events}

\section{Trauma patients}

Unlike elective surgery patients, $25-35 \%$ of all patients with severe physical injuries already show some form 
Table 1 Therapeutic indications for tranexamic acid [27]

\begin{tabular}{l} 
Intravenous administration \\
Prophylaxis and treatment of bleeding due to a local or systemic hyperfibri- \\
nolysis in adults and children over the age of 1 year \\
Bleeding in which hyperfibrinolysis is considered to be involved: \\
Menorrhagia and metrorrhagia \\
Gastrointestinal bleeding \\
Bleeding in urinary tract infections, postoperative bleeding following \\
prostate or urinary tract surgery \\
Ears, nose and throat (ENT) surgery (adenoidectomy, tonsillectomy, dental \\
extractions) \\
Gynecological surgery or obstetric hemorrhage \\
Abdominal and thoracic surgery and other major surgery, e. g. cardiac \\
surgery \\
\hline As antidote in bleeding requiring immediate treatment while on fibrinolytic \\
treatment \\
\hline Oral administration \\
\hline Hypermenorrhea (menorrhagia) \\
\hline Prostatectomy \\
\hline Epistaxis \\
Conisation of the cervix \\
Prophylaxis of recurrent bleeding in traumatic hyphema \\
Dental extraction and other interventions in ENT area in patients with hered- \\
itary coagulopathies \\
Mucosal bleeding in patients with coagulopathies \\
Hereditary angioneurotic edema \\
\hline
\end{tabular}

Table 2 Clinically relevant adverse effects of tranexamic acid (expert opinions) [27]

Gastrointestinal disturbances (nausea, vomiting, diarrhea)
tration
Incidental allergic skin reactions
Infrequent temporal vision impairment
Convulsions

Table 3 Contraindications of tranexamic acid [27]

Hypersensitivity to TXA
Early pregnancy, in late pregnancy only when vitally indicated
Disturbances of color vision
Massive bleeding in the upper urinary tract (risk of ureter obstruction due to
clot)
Acute venous or arterial thrombosis
Severe renal impairment
History of convulsions
Intrathecal and intraventricular injection, intracerebral administration (risk
of cerebral edema and convulsions)
Diseminated intravascular coagulation (DIC) without severe hemorrhage

of coagulopathy when admitted to the shock room. As compared with patients who have been treated for deranged coagulation, these early coagulopathies are associated with a four-fold higher mortality [29]. Profibrinolytic activation appears to play a decisive role in these cases. The extent of posttraumatic HF apparently greatly depends on the extent of shock and the resulting hypoxia and tissue injury. The more pro-
Table 4 Dosage and administration of tranexamic acid According to the SmPC the following dosage guidelines apply to adults [27]

1. Oral administration (1 tablet $=0.5 \mathrm{~g}$ ).

The recommended standard dose is $2-3$ times daily $2-3$ tablets (1-1.5 g), daily dosage $2-4.5 \mathrm{~g}$

2. Intravenous administration ( 1 ampoule $=5 \mathrm{ml}=0.5 \mathrm{~g}$ ) in fibrinolysis: The recommended standard dose is $2-3$ times daily $0.5-1 \mathrm{~g}$ (1-2 ampoules à $5 \mathrm{ml}$ ) by slow intravenous injection $(1 \mathrm{ml} / \mathrm{min})$

3. Intravenous administration in general fibrinolysis:

The recommended standard dose is $1 \mathrm{~g}$ ( 2 ampoules à $5 \mathrm{ml}$ ) every $6-8 \mathrm{~h}$ by slow intravenous injection ( $1 \mathrm{ml} / \mathrm{min})$, corresponding to $15 \mathrm{mg} / \mathrm{kg}$ body weight

nounced the shock, the more severe HF will be (Fig. 1) [8]. The risk of mortality increases with the severity of HF. Several studies revealed that HF exceeding 3\% was associated with a dramatic increase in mortality $[5,6$, 30-32].

The CRASH-2 study published in Lancet in 2010, which comprised 20,211 patients, showed that the use of TXA (loading dose of $1 \mathrm{~g}$ TXA for $10 \mathrm{~min}+1 \mathrm{~g}$ infusion over $8 \mathrm{~h}$ ) compared to matching placebo resulted in a significant reduction of overall (14.5\% vs. $16 \%$, respectively) and hemorrhage-induced (4.9\% vs. $5.6 \%$, respectively) mortality in trauma patients without increasing the rate of thromboembolism [10]; however, the CRASH-2 data should be viewed with caution as it was performed mostly in developing and threshold countries and no influence on transfusion rates by TXA was documented. The CRASH-2 subgroup analyses have shown that all patient groups (severe shock, traumatic brain injury) benefited from TXA administration, no differences being revealed between penetrating and blunt trauma. The CRASH-2 study also did not show any difference with regard to thromboembolic events; however, a post hoc analysis showed that administration of TXA later than $3 \mathrm{~h}$ after the initial trauma was associated with an increase in mortality [33], which suggests that TXA should be administered as early as possible [2].

A retrospective study by Morrison et al. of severely injured soldiers ( $n=896$; TXA: $n=293$ ) demonstrated convincingly that administration of TXA as compared to cryoprecipitate resulted in a clearly lower mortality in the group of patients treated with TXA (massively transfused: $-13.6 \%$; total population: $-6.5 \%$; Fig. 2) [12]. In the group of patients who received massive transfusion TXA was independently associated with less coagulopathy ( $p=0.003$ ) and survival $(\mathrm{OR}=7.23$ ) with a relative risk reduction of mortality of $49 \%$ compared to $27 \%$ in the overall TXA cohort. On the other hand, the rate of thromboembolic events was higher in the TXA group.

In a subsequent study $(n=1332)$ it was shown that patients exclusively treated with cryoprecipitates ( $n=168$ ) exhibited the same survival rates as patients treated only with TXA ( $n=148)$; the survival rate was highest in patients administered both TXA and cryoprecipitate $(n=258)$ [13]. 


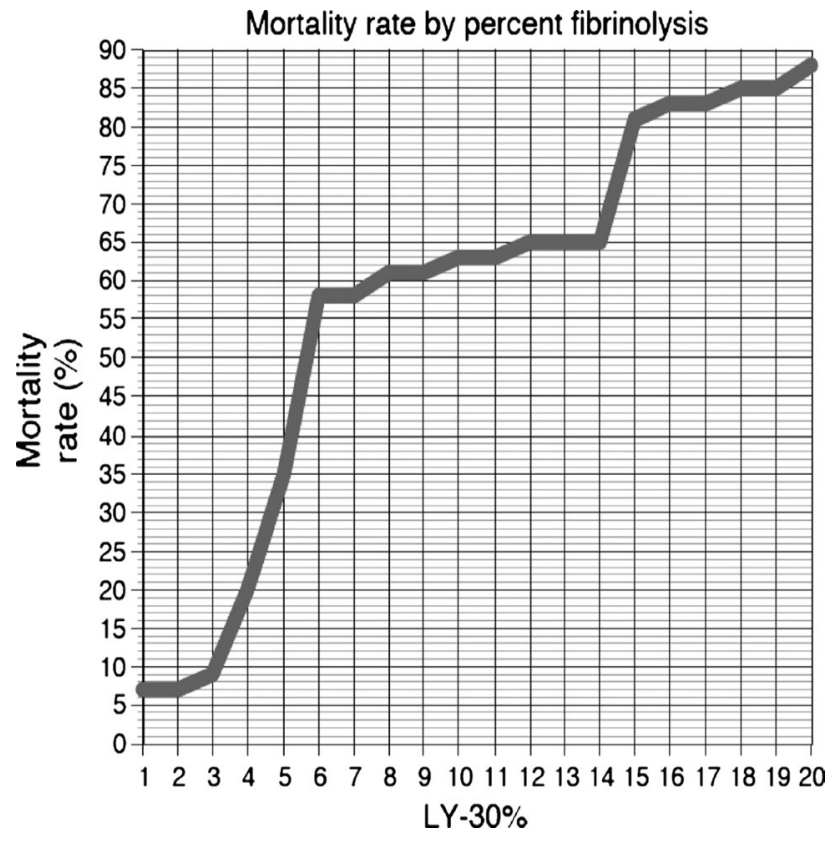

Fig. 1 Mortality rate by percent fibrinolysis. Rate of amplitude reduction 30 minutes after the maximum amplitude (LY30) is reached and its correlation to mortality. HF was defined as more than $7.5 \%$ amplitude reduction 30 minutes after maximal amplitude (LY30). At an LY30 of 3\% or less, 30-day mortality was $9 \%$. However, once the LY30 extended to more than $3 \%$, mortality increased to $20 \%$. Large increases in mortality were also seen at LY30's of greater than $4 \%(35 \%)$, greater than 5\% (58\%), and greater than $15 \%$ (81\%). Reproduced with permission from [6]

Overall Cohort $(n=896)$

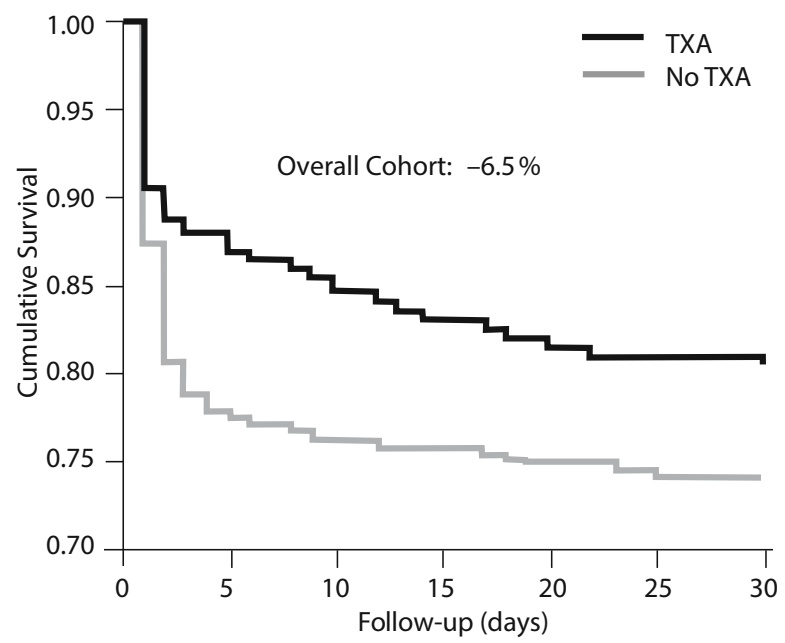

No. at risk

TXA: $293 \quad 220 \quad 172 \quad 159 \quad 155 \quad 152 \quad 148$

In line with the recommendations of the S3 guidelines on treatment of polytrauma/severely injured patients of the German Society of Accident Surgery (Deutsche Gesellschaft für Unfallchirurgie, DGU) [34] an antifibrinolytic agent (e.g. 2 g TXA) should be administered whenever HF is suspected. It is recommended to embed administration of the antifibrinolytic agent in an overall therapy plan for treating coagulopathy, since in the course of HF the consumption of fibrinogen may frequently increase to such an extent that complete defibrination results. This fibrinogen depletion has to be compensated for once HF has been overcome [35] or in other words, the antifibrinolytic agent should be applied before fibrinogen is administered whenever HF is suspected [36]. For polytrauma patients the Austrian Society for Anaesthesiology, Resuscitation and Intensive Care (ÖGARI) and European guidelines [2, 3] recommend early administration of TXA (in the shock room at the latest). The recommended dosages are:

- $1 \mathrm{~g}$ for $10 \mathrm{~min}$, followed by $1 \mathrm{~g}$ over $8 \mathrm{~h} \mathrm{[2]} \mathrm{or}$

- 20-25 mg/kg body weight (BW) followed by continuous administration (1-2 mg/kg BW/h) [3]

- Special care should be taken in the case of intensive care patients in the presence of septicemia or disseminated intravascular coagulopathy (recommendation grade $\mathrm{A})^{2}[37]$

2 Therapeutic recommendations are made on the basis of evidence classes. Recommendation grade A ( $=$ 'is to'): at least one randomized controlled study of overall good quality and consistency, which is directly related to the recommendation in question and has not been extrapolated (evidence levels Ia and Ib [34]).

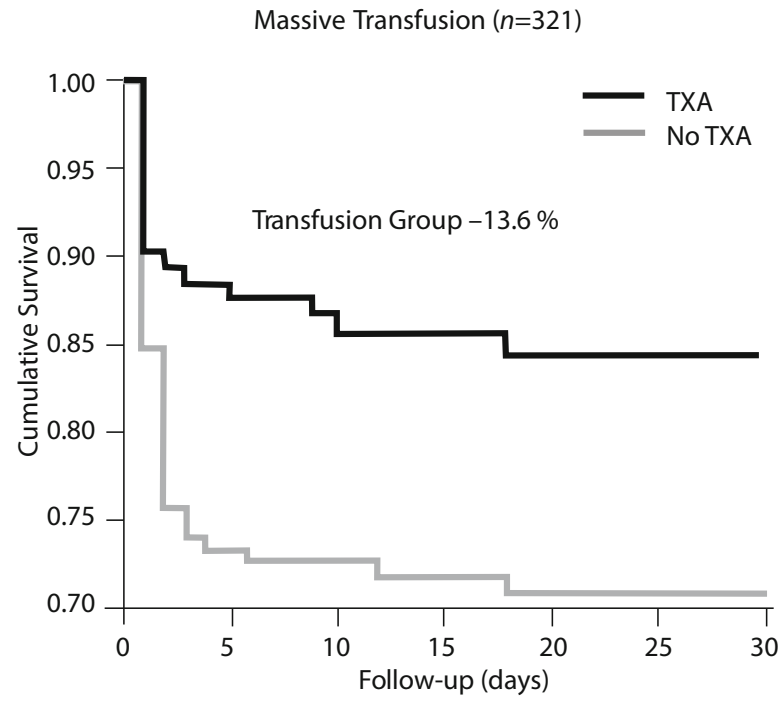

No. at risk

\begin{tabular}{|c|c|c|c|c|c|}
\hline TXA: & 100 & 78 & 74 & 72 & 72 \\
\hline ГХА: 169 & 106 & 87 & 78 & 74 & 74 \\
\hline
\end{tabular}

Fig. 2 Cumulative survival of military TXA administration in the overall cohort and in patients with massive transfusion from the Trauma Emergency Resuscitation (MATTERs) Study. (Data from Morrison et al. [12]) 
Table 5 PPH: results of clinical studies with tranexamic acid in obstetrics

\begin{tabular}{|c|c|c|c|}
\hline Authors & $N$ & Method & Results \\
\hline \multicolumn{4}{|l|}{ Vaginal delivery } \\
\hline Dulcoy-Bouthers et al. [40] & 144 & $\begin{array}{l}\text { RCT, double-blind } \\
4 \mathrm{~g} \text { TXA }+1 \mathrm{~g} / \mathrm{h} \text { in } 6 \mathrm{~h}=10 \mathrm{~g}\end{array}$ & $\begin{array}{l}\text { Bleeding duration } \downarrow \\
\text { Progression to severe PPH } \\
(>800 \mathrm{ml}) \downarrow\end{array}$ \\
\hline Yang et al. [41] & 400 & $\begin{array}{l}\text { RCT (prospective, double-blind) } \\
0.5 \mathrm{~g} \text { vs } 1.0 \mathrm{~g} \text { TXA vs. PAMBA* }\end{array}$ & Total blood loss $\downarrow$ \\
\hline Gungorduk et al. [42] & 454 & $\begin{array}{l}\text { RCT } \\
\text { TXA } 1.0 \mathrm{~g} \text { vs. placebo }\end{array}$ & $\begin{array}{l}\text { Blood loss } \downarrow \\
\text { Progression to severe PPH }(>500 \mathrm{ml}) \downarrow\end{array}$ \\
\hline Bouet et al. [43] & 289 & $\begin{array}{l}\text { Retrospective single centre analysis of policy } \\
\text { before and after use of high dose TXA } 10 \mathrm{~g}\end{array}$ & No difference in blood loss \\
\hline \multicolumn{4}{|l|}{ Cesarean delivery } \\
\hline Goswami et al. [44] & 90 & $\begin{array}{l}\text { RCT (prospective, double-blind) } \\
10 \mathrm{mg} / \mathrm{kg} \mathrm{TXA} \text { in } 20 \mathrm{~min} \text {, then } 10 \mathrm{vs.} 15 \mathrm{mg} / \mathrm{kg} \\
\text { TXA vs placebo }\end{array}$ & $\begin{array}{l}\text { Total blood loss in both TXA groups } \\
\text { significantly less with } 15 \mathrm{mg} / \mathrm{kg}\end{array}$ \\
\hline Gai et al. [45] & 180 & $\begin{array}{l}\text { RCT (multi centre, prospective, randomized con- } \\
\text { trolled) } \\
1 \mathrm{~g} \text { TXA over } 5 \mathrm{~min}, 10 \mathrm{~min} \text { before CS vs not }\end{array}$ & Blood loss until $2 \mathrm{~h}$ after delivery $\downarrow$ \\
\hline Abdel Aleem et al. [46] & 740 & $\begin{array}{l}\text { RCT (Single centre, open, controlled) } \\
1 \mathrm{~g} \text { TXA over } 10 \mathrm{~min}, 10 \mathrm{~min} \text { before CS vs. not }\end{array}$ & $\begin{array}{l}\text { Blood loss until } 2 \mathrm{~h} \text { after delivery } \downarrow \\
\text { Hemoglobin decline } \downarrow\end{array}$ \\
\hline Sekhavat et al. [47] & 90 & $\begin{array}{l}\text { RCT (prospective, randomized, double-blind) } \\
1 \mathrm{~g} \text { TXA over } 10 \mathrm{~min}, 10 \mathrm{~min} \text { before CS vs. not }\end{array}$ & $\begin{array}{l}\text { Blood loss until } 2 \mathrm{~h} \text { after delivery } \downarrow \\
\text { Hemoglobin decline } \downarrow\end{array}$ \\
\hline Halder et al. [48] & 100 & $\begin{array}{l}\text { Case-control study } \\
\text { TXA before CS vs not }\end{array}$ & $\begin{array}{l}\text { Blood loss until } 2 \text { days postpartum } \downarrow \\
\text { Hemoglobin decline } \downarrow\end{array}$ \\
\hline Movafegh et al. [49] & 100 & $\begin{array}{l}\text { RCT (prospective, double-blind, randomized, } \\
\text { controlled) } \\
10 \mathrm{mg} / \mathrm{kg} \text { TXA vs placebo }\end{array}$ & $\begin{array}{l}\text { Blood loss until } 2 \mathrm{~h} \text { postpartum } \downarrow \\
\text { Hemoglobin decline } \downarrow\end{array}$ \\
\hline Sentürk et al. [50] & 223 & $\begin{array}{l}\text { RCT (prospective, double-blind, placebo controlled) } \\
10 \mathrm{mg} / \mathrm{kg} \text { for } 5 \mathrm{~min} \text {, } \\
10 \mathrm{~min} \text { before CS vs placebo }\end{array}$ & Intra- and postoperative blood loss $\downarrow$ \\
\hline Xu et al. [51] & 174 & $\begin{array}{l}\text { Randomized case-control study } \\
10 \mathrm{mg} / \mathrm{kg} \text { TXA before CS or not }\end{array}$ & $\begin{array}{l}\text { Blood loss until } 2 \mathrm{~h} \text { postpartum } \downarrow \\
\text { Progression to PPH } \downarrow\end{array}$ \\
\hline Gohel et al. [52] & 100 & $\begin{array}{l}\text { Randomized, prospective case-control study } \\
1 \mathrm{~g} \text { TXA over } 5 \mathrm{~min}\end{array}$ & Blood loss until $2 \mathrm{~h}$ postpartum $\downarrow$ \\
\hline Shahid et al. [53] & 74 & $\begin{array}{l}\text { RCT (prospective, randomized, double-blind) } \\
1 \mathrm{~g} \text { TXA }\end{array}$ & Intraoperative blood loss $\downarrow$ \\
\hline Gungorduk et al. [54] & 660 & $\begin{array}{l}\text { RCT (prospective, double-blind, placebo controlled) } \\
1 \mathrm{~g} \text { TXA }\end{array}$ & Intraoperative blood loss $\downarrow$ \\
\hline
\end{tabular}

Rapid bolus administration of TXA might result in a further drop in blood pressure in shock patients and should be avoided [23].

\section{Postpartum hemorrhage}

Postpartum hemorrhage (PPH) is among the leading causes of maternal mortality worldwide [38, 39]. In a series of controlled studies on PPH in vaginal deliveries TXA proved capable of reducing the extent of peripartum bleeding and time to hemostasis [40-43]. Similarly, administration of TXA in the course of cesarean sections resulted in a reduction of bleeding time and blood loss and, in some studies, of transfusion needs (Table 5; [44-54]).

According to a Cochrane analysis (2010) of two randomized, controlled studies administration of $0.5 \mathrm{~g}$ and $1 \mathrm{~g}$, respectively, of TXA reduced both blood loss and transfusion needs after vaginal births and cesarean sections [55]. A systematic review (1760 births) also found that the administration of TXA as compared with placebo resulted in a significant reduction of blood loss and the frequency of allogenic transfusion (RR 0.34, 95\%CI 0.2-0.6) [56]. This finding is supported by a recent meta-analysis (2531 births) comprising 11 studies (Table 7; RR 0.23, 95\%CI 0.10-0.57, $P<0.01$ ) [57].

Accordingly, the European Society of Anaesthesiology (ESA) recommends administration of TXA in the case of peripartum and postpartum hemorrhage in order to reduce the extent of blood loss, the duration of bleeding and the need for allogeneic blood products (1B) [3]. Moreover, there is a $2 \mathrm{C}$ recommendation for the administration of TXA prior to cesarean section. In the case of antepartum hemorrhage TXA administration may be taken into consideration (2B) [3]. 
An international interdisciplinary expert consensus recommends for the treatment of postpartum hemorrhage the administration of $2 \mathrm{~g}$ TXA i. v. prior to supplementing fibrinogen, with dosages ranging from 1 to $3 \mathrm{~g}$ [58].

\section{Menometrorrhagia}

Pathologically excessive and/or prolonged uterine bleeding is one of the most frequent symptoms in women suffering from coagulation abnormalities [59]. The prevalence of menorrhagia in patients suffering from von Willebrand disease is $32-100 \%$ (platelet dysfunction: 5-98\%; rare factor deficiency states 35-70\%) [60-62].

According to various studies TXA administered to menorrhagic women resulted in a significant reduction of menstrual blood loss while not increasing the risk of thrombosis [63] and is successfully used to treat menorrhagia associated with a number of coagulopathies $[64,65]$. In patients with hypermenorrhoea and/or menorrhagia TXA (administered from the 1st to the 5 th day of the cycle) can reduce blood loss by $35-60 \%[60,66]$.

The recommended dose is 2-3 tablets TXA (1-1.5 g) 3-4 times a day for 3-4 days (starting immediately after onset of heavy bleeding). In the case of excessive bleeding the dose may be increased but should not exceed a maximum daily dose of $4 \mathrm{~g}$ [27].

\section{Mucocutaneous bleeding with coagulopathies}

Antifibrinolytics are also used for many hemorrhagic conditions, and especially for mucosal bleeding of the nose or gums. Mouthwashes with antifibrinolytics are useful to prevent bleeding after tooth extractions $[67,68]$. In many cases of mild to moderate mucosal bleeding topical and systemic administration of antifibrinolytics combined with topical hemostasis will be sufficient [69].

In patients suffering from hemophilia, von Willebrand disease or congenital platelet dysfunctions, topical $^{3}$ (in the form of mouthwashes), buccal or intravenous administration of TXA will help reduce hemorrhage and blood loss, particularly mucosal bleeding. In cases of moderate and mild hemophilia, von Willebrand disease type 1 (mild deficiency) and storage pool disease (thrombocyte granular defect) it is recommended to use desmopressin jointly with TXA [62, 70, 71]. On the other hand, combined administration of activated factor concentrate (AntiInhibitor Coagulant Complex, FEIBA/Baxter) and TXA is not recommended in view of the rather unpre-

\footnotetext{
3 Topical administration is not mentioned in the prescribing information.
}

dictable increase in coagulability (hypercoagulability). In hemorrhage of the upper urinary tract TXA may favour the formation of obstructive clots in the bladder, hence it is not recommended either.

\section{Gastrointestinal bleeding}

In acute bleeding in the upper gastrointestinal tract TXA reduces mortality $[3,72,73]$, with a recent Cochrane analysis reporting a relative mortality risk of 0.60 and a relative after-bleeding risk of 0.72 [74]. This review comprised eight randomized controlled studies published between 1973 and 2011; however, the authors do not recommend routine use of TXA in the case of gastrointestinal bleeding ("tranexamic acid cannot be recommended for routine clinical practice"), pointing to a current HALT-IT study for which a total of 8000 patients with gastrointestinal bleeding are to be recruited. To date (November 2016) more than 5670 persons have been included. ${ }^{4}$

\section{Tranexamic acid in elective applications}

\section{Orthopedic surgery}

Administration of antifibrinolytics in the course of major orthopedic surgery (total hip or knee replacement) is associated with a reduction of perioperative blood loss and allogeneic blood transfusions [75-78]. A comprehensive retrospective cohort study $(n=$ 872,416 ) has furthermore shown that TXA results in a significant reduction of the probability of transfusion in patients undergoing total hip or knee replacement (OR 0.31-0.38; $p<0.001$ ) without increasing the risk of thromboembolism, kidney failure or combined complications [79]. This is also confirmed by a metaanalysis of 46 randomized controlled studies on 2925 orthopedic surgery patients, which also pointed to a reduction of total intraoperative and postoperative blood loss [80].

In patients undergoing total knee replacement without blood arrest, blood transfusions could be completely dispensed with, when TXA was administered twice (preoperatively and postoperatively i. v. $15 \mathrm{mg} / \mathrm{kg} \mathrm{BW}$ ), while $32 \%$ of patients in the control group required transfusions. In addition, postoperative drainage blood loss was significantly lower vs. placebo, and the hematocrit and hemoglobin values of the verum group were higher [81]. In patients undergoing total knee replacement, oral TXA (1 g preoperatively followed by $1 \mathrm{~g}$ every $6 \mathrm{~h}$ over a period of $18 \mathrm{~h}$ postoperatively) proved effective in reducing postoperative fibrinolysis [82, 83]. In hip surgery TXA $(15 \mathrm{mg} / \mathrm{kg}$ BW as either a single or double bolus at the start of the intervention and $3 \mathrm{~h}$ thereafter) resulted

\footnotetext{
4 Hemorrhage ALleviation with Tranexamic acid - In Testinal system; the study protocol is available on the Internet: http://haltit. lshtm.ac.uk/.
} 
Table 6 Recognized indications of tranexamic acid in pediatrics (expert opinion)

Excessive fibrinolysis (e.g. liver transplantation, medication induced)

Adjuvant as hemostatic agent, in hemophilia and von Willebrand disease (e. g. dentistry, not in renal bleeding!)

Mucosal bleeding (topical ${ }^{\mathrm{a}}$, oral, intravenous), exception: bleeding of the upper urinary tract

Primary and adjuvant in hereditary thrombopathies/thrombopenia [102, 103]

PAI 1 deficiency, $\alpha_{2}$-plasmin inhibitor deficiency, hereditary telangiectasia

Adjuvant in:

acquired thrombocytopenia

cardiac surgery

bypass surgery

aTopical use: TXA (solution for injection) is locally applied without dilution or diluted with $\mathrm{NaCl} 0.9 \%$; when applied in the mouth the swallowed amount should be added to the total dosage. The topical application is not included in the SmPC

in a reduction of allogeneic blood transfusions but increased the risk of hypercoagulability [84-86].

The ESA recommends the use of TXA in the case of total hip endoprostheses (TEP), knee joint replacement and major spinal surgery (2A) [3]. It should be pointed out, however, that TXA may cause hypercoagulability in some patient groups (pre-existing thromboembolic events, hip fracture/cancer surgery, age $>60$ years, women). It is therefore recommended to perform an individual risk-benefit analysis rather than administer TXA routinely $(2 \mathrm{~A})$.

\section{Cardiovascular surgery/coronary artery bypass graft (CAGB) interventions}

Numerous studies show that the use of antifibrinolytic agents in the course of cardiovascular operations reduces blood loss; it seems that TXA is superior to EACA with regard to perioperative transfusions [87]. Since the withdrawal of aprotinin from the market, at the latest, TXA has been the standard antifibrinolytic treatment in heart surgery [88]. The two guidelines for anticoagulation management published by the Society of Thoracic Surgeons (STS) and the European Association for Cardio-Thoracic Surgery (EACTS) deal with the intraoperative use of antifibrinolytics in heart surgery: both TXA and EACA are consistently recommended to minimise blood loss and transfusion needs $[1,89]$. In a double-blind, randomized, placebo controlled trial ( $n=222$ ) TXA (preoperative bolus followed by intraoperative permanent infusion) reduced drainage volume and transfusion needs in elective coronary artery bypass graft (CABG) [90]. Similar results were obtained in a meta-analysis of 25 RCTs ( $n=5411)$ and large-scale observational studies ( $n=$ 5977), which confirmed the efficacy of TXA, as compared with placebo, in reducing blood loss, allogeneic blood transfusion needs and the reoperation rate due to postoperative hemorrhage [91].
The ESA guidelines recommend the use of TXA prior to CABG interventions (1A); likewise, intraoperative administration of TXA should be considered in order to reduce perioperative bleeding in the course of high, medium and low-risk cardiovascular surgery (1A). Also, topical (see footnote 3) application of TXA in the thoracic cavity is recommended to reduce postoperative blood loss after CABG (1C).

A current dose comparison study on patients undergoing heart surgery while connected to a heartlung machine revealed, up to day 7 , a higher efficacy in terms of blood loss, lower incidence of transfusions and reoperation rate in the high-dose group (TXA $30 \mathrm{mg} / \mathrm{kg}$ BW bolus $+16 \mathrm{mg} / \mathrm{kg} \mathrm{BW} / \mathrm{h}$ ) as compared with the low-dose group (TXA $10 \mathrm{mg} / \mathrm{kg}$ BW bolus $+1 \mathrm{mg} / \mathrm{kg} \mathrm{BW} / \mathrm{h}$ ), while reporting no difference with regard to the incidence of blood product transfusion; in other words, the percentage of patients that required blood transfusions up to 7 days after the intervention was not reduced [92].

TXA dosages in cardiac surgery with cardio-pulmonary bypass (CPB) currently relate mostly to those used in the BART Study [9]: TXA bolus $30 \mathrm{mg} / \mathrm{kg}$ BW prior to CPB, followed by continuous infusion with $16 \mathrm{mg} / \mathrm{kg} \mathrm{BW} / \mathrm{h}$ up to the end of the operation [9]. It should be noted that open heart surgery in particular carries a higher risk of seizures caused by even moderate doses of TXA

(24 mg/kg BW/day) [84].

In one Austrian centre (Graz) the incidence of seizures was successfully reduced by lowering, on a trial basis, the TXA dose to one half of the dose used in the BART study (bolus for all patients $1 \mathrm{~g}[=10 \mathrm{ml}]$ prior to HLM; immediately thereafter infusion of $8 \mathrm{mg} / \mathrm{kg} \mathrm{BW} / \mathrm{h}$ up to the end of surgery): While the efficacy was slightly attenuated, virtually no seizures were observed (W. Toller, personal communication).

\section{Liver surgery}

\section{Orthotopic liver transplantation}

In orthotopic liver transplantations (OLT) antifibrinolytic therapy reduces both blood loss and transfusion needs (B) [3]. A meta-analysis has shown that both TXA and aprotinin reduce the need for erythrocyte concentrates [93]. Moreover, a Cochrane review concluded that antifibrinolytic therapy helps reduce blood loss and perioperative transfusion needs [94], with TXA and EACA being equally effective.

Treatment of hyperfibrinolysis (confirmed by the presence of microvascular blood oozing and/or thrombelastography or rotation thromboelastometry, TEG/ROTEM measurement) with antifibrinolytics is recommended; lowest effective doses are uncertain, TXA being currently 
Table 7 Dosing of tranexamic acid in children according to current guidelines (modified according to [108, 109])

\begin{tabular}{|c|c|c|c|}
\hline $\begin{array}{l}\text { Children and } \\
\text { adolescents }\end{array}$ & & Bolus & Maintenance dose from day 0 \\
\hline \multirow[t]{2}{*}{$<50 \mathrm{~kg}$} & Oral & $15-25 \mathrm{mg} / \mathrm{kg}$ on preceding evening or $1.5-2 \times$ dosage on day of surgery & $15-25 \mathrm{mg} / \mathrm{kg} 3-4 \times$ daily \\
\hline & Intravenous & $10-15 \mathrm{mg} / \mathrm{kg}$ on day of surgery & $10-15 \mathrm{mg} / \mathrm{kg} 3 \times$ daily \\
\hline \multirow[t]{2}{*}{$\geq 50 \mathrm{~kg}$} & Oral & $1.0-1.5 \mathrm{~g}$ on preceding evening or $1.5-2 \times$ dosage on day of surgery & $1.0-1.5 \mathrm{~g} 3-4 \times$ daily \\
\hline & Intravenous & $0.5-1.0 \mathrm{~g}$ on day of surgery & $0.5-1.0 \mathrm{~g} 3 \times$ daily \\
\hline
\end{tabular}

administered in gradually increasing dosages of $1-2 \mathrm{~g}[3]$.

\section{Liver resection}

In the course of liver resections for hepatocellular carcinoma TXA reduced average total blood loss and transfusion needs significantly as compared with placebo [95]. A Cochrane review also reported a reduction of allogeneic blood transfusions in patients receiving TXA or aprotinin [96].

According to ESA recommendations [3] antifibrinolytic therapy should be considered in patients with cirrhosis of the liver and liver resection (2C).

\section{Prostate surgery}

Intraoperative blood loss during prostate surgery is significantly lower with TXA than with placebo [97]. This was also confirmed by smaller-scale studies on prostatectomy with oral TXA (post-op 1.5-3 g/day for 3 days) [98, 99].

After initial intravenous therapy during the first three postoperative days, $2-3$ tablets (1-1.5 g) may be given twice or three times daily for 7 days or until hematuria can no longer be detected macroscopically [27].

\section{Conisation and gynecologic oncologic surgery}

TXA reduces both the incidence of secondary hemorrhage after cervical conisation [100] (B) and the incidence of perioperative bleeding during gynecologic oncologic surgery [101] (C) [3].

According to the prescribing information the dosage of TXA after cervical conisation should be 3 tablets ( $1.5 \mathrm{~g}$ ) three times a day for 12-14 days post operatively [25]; however, administration of TXA is not recommended for benign gynecological interventions, such as myomectomies (2B) $[3,102]$.

\section{Pediatrics and pediatric surgery}

In pediatrics TXA has a wide field of application (Table 6). It is used to prevent and treat hemorrhage and to combat hyperfibrinolysis; however, literature data on the use in children is greatly limited.
In children undergoing cardiac surgery or surgery for scoliosis with a high bleeding risk, TXA has significantly reduced perioperative blood loss and the need for erythrocyte concentrates [103, 104]. Similar effects have also been reported in the context of pediatric craniosynostosis operations [105].

Perioperative antifibrinolytic therapy to reduce blood loss and transfusion needs is proposed for both heart surgery and non-cardiac surgical interventions (2A) [3].

Optimum dosages for pediatric patients have not yet been fully established for the entire range of indications (dosage range, bolus: $10-100 \mathrm{mg} / \mathrm{kg}$ BW; infusion rate: $1-10 \mathrm{mg} / \mathrm{kg} \mathrm{BW} / \mathrm{h})$. In principle, repeated administration of TXA appears to be more effective in pediatric heart surgery than a single bolus [106].

In a pharmacokinetic study of heart operations the recommended TXA dosage plan for children was a loading dose of $6.4 \mathrm{mg} / \mathrm{kg}$ BW with weightadapted infusion rates ranging from $3.1 \mathrm{mg} / \mathrm{kg} \mathrm{BW} / \mathrm{h}$ to $2.0 \mathrm{mg} / \mathrm{kg} \mathrm{BW} / \mathrm{h}$ (BW 5-40 kg) [107].

Recent guidelines for the therapy of congenital platelet dysfunctions [108, 109] recommend for children the dosage plan summarized in Table 7 .

The prescribing information on Cyklokapron ${ }^{\circledR}$ recommends different dosages for children [27]:

- oral: $15-25 \mathrm{mg} / \mathrm{kg} \mathrm{BW}$ up to a maximum of $1.5 \mathrm{~g}$ 2-3× daily

- i. v.: For currently approved indications for children from the first year of life onwards $20 \mathrm{mg} / \mathrm{kg}$ BW/day; for these indications, only limited data on efficacy, dosages and safety are so far available.

Mouth washes (see footnote 3) with TXA are useful for the prevention and treatment of hemorrhage in the buccal mucosa. TXA can also be diluted in a drinkable liquid. If the liquid is swallowed after rinsing, the amount has to be allowed for in the overall dose [102].

\section{Epistaxis and tonsillectomy}

Along with satisfactory results achieved by the topical (see footnote 3) application of TXA in the treatment of idiopathic epistaxis [110], a European randomized double-blind cross-over study ( $n=118$ ) found TXA ( $3 \mathrm{~g} /$ day) also to be effective in patients suffering from epistaxis associated with hereditary hemorrhagic telangiectasia in that the monthly duration of epis- 
taxis was significantly shortened as compared with placebo $(-17.3 \%, p=0.0005)$ [111].

In the case of epistaxis TXA is at first applied topically to the nasal mucosa (moistened strip of gauze) by tamponading the nose cavum; if recurrent bleeding is expected the patient should be given 2 tablets ( $1 \mathrm{~g}$ ) 3 times a day for 4-10 days before the tamponade is removed. In patients with a body weight less than $30-50 \mathrm{~kg}$ pediatric dose recommendations should be strictly adhered to.

A systematic review of older studies on the use of TXA with tonsillectomies indicated a significant reduction of blood loss as compared with the control groups, while TXA had no influence at all on the incidence of postoperative bleeding [112].

\section{Neurosurgical interventions and subarachnoid hemorrhage}

In the course of neurosurgical interventions TXA ( $1 \mathrm{~g}$ immediately after diagnosis of an aneurysmal subarachnoid hemorrhage [aSAH], followed by $1 \mathrm{~g}$ every $6 \mathrm{~h}$ up to the time the aneurysm has been corrected) reduced the mortality risk due to early rebleeding by 80\% [113]. Data from randomized controlled studies on the efficacy and safety of antifibrinolytics in brain surgery are rare and mostly older than the above cited Hillman study, or they relate to aprotinin, which was withdrawn from the market in 2007 [114]. A Cochrane review published in 2013 included all randomized controlled studies published between 1973 and 2002 [115]. The authors came to the conclusion that the short-term data were promising but felt that the studies were too heterogeneous to justify a general recommendation to use antifibrinolytics in the treatment of aSAB. Similarly, the European Stroke Organization is not ready to make such a recommendation on the basis of the data so far available [116].

The joint guidelines of the Austrian Neurological Society (Österreichische Gesellschaft für Neurologie, ÖGN) and the German Neurological Society (Deutsche Gesellschaft für Neurologie, DGN) published in 2008 explicitly do not recommend a prophylactic administration of antifibrinolytics for SAH ( $\downarrow \downarrow)$ [117], a position that was repeated in the updated version of 2012 [118].

The CRASH-2 intracranial bleeding study found that while patients with intracranial bleeding due to traumatic brain injury who were given TXA showed a significantly better outcome regarding the combined endpoint "poor outcome" (TXA vs placebo: $45 \%$ vs $58 \%$ of patients), the difference between TXA and placebo was not significant with regard to the individual parameters mortality ( $p=0.06)$, recurring focal ischemia ( $p=0.20)$, re-bleeding $(p=0.22)$ and substantial increase in bleeding $(p=0.13)$ [119].
Currently a number of studies are underway to evaluate the earliest possible short-term administration of TXA in patients with SAH (ULTRA), intracerebral bleeding (STOP-AUST) or traumatic brain injury (CRASH-3) [120-122].

\section{TXA not recommended by the authors}

According to expert opinion, administration of TXA is not recommended in the following cases:

- Renal failure

- Epilepsy

- Benign gynecological interventions (e.g. myomectomy)

- In combination with activated factor concentrate (FEIBA, factor VIII inhibitor bypass activity; $1 \mathrm{ml}=$ $25 \mathrm{E}^{*}$ factor VIII inhibitor bypass activity; see footnote 3 )

- Fibrinolysis due to disseminated intravascular coagulation without any significant bleeding

If TXA were still to be administered, this should only be done in patients in whom an activation of the fibrinolytic system preponderates and in the presence of severe bleeding.

\section{Summary}

TXA has been used for decades to prevent and treat clinically relevant HF and more generally for the prevention and treatment of bleeding due to a variety of causes. In the course of major surgical interventions (especially cardiac surgery, orthopedic surgery and liver transplantations) TXA reduces perioperative blood loss and the need for transfusions. In trauma patients with partly excessive bleeding TXA can also reduce mortality, in particular if administered within a narrow time frame after injury.

Despite extensive experience there still remain open questions as to the uses of TXA, which would ideally have to be dealt with in future studies:

- In some fields of application there is a need to define the optimum TXA dosage, since, side by side with the dose recommendations found in current summaries of product characteristics (SPC), both clinical studies and the practice of centres with considerable experience have in the meantime provided evidence that numerous other regimes, such as half doses, administration of a bolus, administration twice, preoperatively and postoperatively, seem to be equally effective.

- As to the risk of thromboembolic complications findings are still partly contradictory, and it is not yet clear which patients are at risk at all and which of them run the highest risk.

- This is also true of seizures observed with higher TXA doses and in the course of cardiac surgery. 
- It would be highly desirable to develop better and more sensitive diagnostic methods to differentiate more easily between hyperfibrinolytic conditions and other coagulopathies or DIC. Likewise, suitable tests ought to be developed to identify more precisely patients that might be treated with TXA and those likely not to benefit from such treatment.

\section{Outlook}

More extensive or more precise answers are expected from current randomized controlled studies comprising several thousands of patients, such as, for example, the Australian PATCH study (Pre-hospital Antifibrinolytics for Traumatic Coagulopathy and Haemorrhage - NCT02187120), which investigates early administration of TXA to severely injured patients to improve survival rates and convalescence, and the Danish PeTraH study (NCT01940419), which evaluates TXA administered to prevent bleeding in cases of benign hysterectomy. The French TRAAP study (Tranexamic Acid for Preventing Postpartum Haemorrhage Following a Vaginal Delivery - NCT02302456) investigates whether low-dose TXA immediately after vaginal delivery can reduce the incidence of postpartum hemorrhage in women having received oxytocin. Moreover, the international WOMAN trial (World Maternal Antifibrinolytic trial - NCT00872469), a randomized double-blind study, in which more than 20,000 women from 21 countries with postpartum bleeding are enrolled, evaluates the efficacy of early administration of TXA with regard to the endpoints death, hysterectomy, surgical interventions, blood transfusions and other vascular events (http://www. womantrial.lshtm.ac.uk/).

Funding The organization and running of meetings as well as the subsequent coordinating process and publication of the present review article were financed through an unrestricted grant by Pfizer Corp. Austria. The organization of the meeting and the publication process was supported by Update Europe - Society for Postgraduate Medical Training.

Open access funding provided by Medical University of Vienna.

Conflict of interest W. Toller declares that he has no competing interests. I. Pabinger: payment for lectures and Advisory Board Meetings of Bayer, Boehringer, Biotest, CSL Behring, Pfizer companies. D. Fries: Astra Zeneca, AOP Orphan, Baxter, Bayer, BBraun, Biotest, CSL Behring, Delta Select, Dade Behring, Edwards, Fresenius, Glaxo, Haemoscope, Hemogem, Lilly, LFB, Mitsubishi Pharma, NovoNordisk, Octapharm, Pfizer, Tem-Innovation. H. Schöchl: study grants from CSL Behring and Tem International and speaker fees CSL Behring, Baxter, Baxalta, Bayer, Pfizer and Tem International. W. Streif: payment for lectures and counselling of Bayer, Baxalta, Biotest, CSL-Behring, Octapharma, Orphan Medical, Pfizer companies.

Open Access This article is distributed under the terms of the Creative Commons Attribution 4.0 International License (http://creativecommons.org/licenses/by/4.0/), which permits unrestricted use, distribution, and reproduction in any medium, provided you give appropriate credit to the original author(s) and the source, provide a link to the Creative Commons license, and indicate if changes were made.

\section{References}

1. International Consortium for Evidence Based Perfusion, Baker RA, Dickinson TA, FitzGerald DJ, Likosky DS, Shann KG, Society of Thoracic Surgeons Blood Conservation Guideline Task Force, Ferraris VA, Brown JR, Despotis GJ, et al. 2011 update to the Society of Thoracic Surgeons and the Society of Cardiovascular Anesthesiologists blood conservation clinical practice guidelines. Ann Thorac Surg. 2011;91(3):944-82.

2. Rossaint R, Bouillon B, Cerny V, Coats TJ, Duranteau J, et al. The European Guidelines on management of major bleeding following major trauma: fourth edition. Crit Care. 2016;20:R100.

3. Kozek-Langenecker SA, Afshari A, Albaladejo P, Santullano CA, De Robertis E, et al. Management of severe perioperative bleeding: guidelines from the European Society of Anaesthesiology. EurJ Anaesthesiol. 2013;30:270-382.

4. Hess JR, Brohi K, Dutton RP, Hauser CJ, Holcomb JB, et al. The coagulopathy of trauma: a review of mechanisms. J Trauma. 2008;65:748-54.

5. Schöchl H, Cadamuro J, Seidl S, Franz A, Solomon C, et al. Hyperfibrinolysis is common in out-of-hospital cardiac arrest: results from a prospective observational thromboelastometrystudy. Resuscitation. 2013;84:454-9.

6. Cotton BA, Harvin JA, Kostousouv V, Minei KM, Radwan $\mathrm{ZA}$, et al. Hyperfibrinolysis at admission is an uncommon but highly lethal event associated with shock and prehospital fluid administration. J Trauma Acute Care Surg. 2012;73:365-70.

7. Bouwmeester FW, Bolte AC, van Geijn HP. Pharmacological and surgical therapy of primary postpartum hemorrhage. Curr Pharm Des. 2005;11:759-73.

8. Brohi K, Cohen MJ, Davenport RA. Acute coagulopathy of trauma: mechanism, identification and effect. Curr Opin CritCare. 2007;13(6):680-5.

9. BART Investigators, Fergusson DA, Hébert PC, Mazer CD, Fremes S, MacAdams C, et al. A comparison of aprotinin and lysine analogues in high-risk cardiac surgery. $\mathrm{N}$ Engl J Med. 2008;358(22):2319-31.

10. Shakur H, Roberts I, Bautista R, Caballero J, Coats T, et al. Effects of tranexamic acid on death, vascular occlusive events, and blood transfusion in trauma patients with significant haemorrhage (CRASH-2): a randomised, placebocontrolled trial. Lancet. 2010;376:23-32.

11. Sydenham E. Thousands of lives could be saved using tranexamic acid for patients with bleeding trauma. Inj Prev. 2011;17:211.

12. Morrison JJ, Dubose JJ, Rasmussen TE, Midwinter MJ. Military application of tranexamic acid in trauma emergency resuscitation (MATTERs) study. Arch Surg. 2012;147:113-9.

13. Morrison JJ, Ross JD, Dubose JJ, Jansen JO, Midwinter MJ, Rasmussen TE. Association of cryoprecipitate and tranexamic acid with improved survival following wartime injury: findings from the MATTERs II Study. JAMA Surg. 2013;148:218-25.

14. Maegele M, Schöchl H, Cohen MJ. An update on the coagulopathy of trauma. Shock. 2014;41(Suppl 1):21-5. 
15. Solomon C, Collis RE, Collins PW. Haemostatic monitoring during postpartum haemorrhage and implications for management. BrJAnaesth. 2012;109:851-63.

16. Stibbe J, Kluft C, Brommer EJP. Enhanced fibrinolytic activity during cardiopulmonary bypass in open-heart surgery in man is caused by extrinsic (tissue-type) plasminogen activator. Eur JClin Invest. 1984;14:375-82.

17. Steib A, Gengenwin N, Freys G, Boudjema K, Levy S, Otteni JC. Predictive factors of hyperfibrinolytic activity during liver transplantation in cirrhotic patients. $\mathrm{Br} J$ Anaesth. 1994;73:645-8.

18. Porte RJ. Coagulation and fibrinolysis in orthotopic liver transplantation: current views and insights. Semin Thromb Hemost. 1993;19:191-6.

19. Schöchl H, Voelckel W, Grassetto A, Schlimp CJ. Practical application of point-of-care coagulation testing to guide treatment decisions in trauma. J Trauma Acute Care Surg. 2013;74(6):1587-98

20. Raza I, Davenport R, Rourke C, Platton S, Manson J, et al. The incidence and magnitude of fibrinolytic activation in trauma patients. JThromb Haemost. 2013;11:307-14.

21. Larsen OH, Fenger-Eriksen C, Ingerslev J, Sørensen B. Improved point-of-care identification of hyperfibrinolysis is needed. Thromb Res. 2012;130(4):690-1.

22. Moore HB, Moore EE, Gonzalez E, Chapman MP, Chin TL, et al. Hyperfibrinolysis, physiologic fibrinolysis, and fibrinolysis shutdown: the spectrum of postinjury fibrinolysis and relevance to antifibrinolytic therapy. J Trauma Acute CareSurg. 2014;77:811-7.

23. Valle E, Allen C, Van Haren R, Jouria JM, Li H, Livingstone AS, et al. Do all trauma patients benefit from tranexamic acid? JTrauma Acute Care Surg. 2014;76:1373-1137.

24. de Leede-van der Maarl MG, Hilkens P, Bosch F. The epileptogenic effect of tranexamic acid. J Neurol. 1999;246:843.

25. Rossaint R, Bouillon B, Cerny V, Coats TJ, Duranteau J, et al. Management of bleeding following major trauma: an updated European guideline. Crit Care. 2010;14:R52.

26. McCormack PL. Tranexamic acid: a review of its use in the treatment of hyperfibrinolysis. Drugs. 2012;72:585-617.

27. Bundesamt für Sicherheit im Gesundheitswesen. SmPC Cyklokapron 2017. https://aspregister. basg.gv.at/aspregister/faces/aspregister.jspx? afrLoop $=37436459280850395 \&$ \& afrWindowMode $=0$ \& adf.ctrl-state $=1 \mathrm{mfx} 7 \mathrm{sq6g}$. $4 . \quad$ Accessed February 2,2017.

28. Lier H. Gerinnungsstabilisierung bei Polytrauma: Immer Tranexamsäure? Rettungsdienst. 2014;37:42-5.

29. Brohi K, Singh J, Heron M, Coats T. Acute traumatic coagulopathy. JTrauma. 2003;54(6):1127-30.

30. Chapman MP, Moore EE, Ramos CR, Ghasabyan A, Harr JN, et al. Fibrinolysis greater than $3 \%$ is the critical value for initiation of antifibrinolytic therapy. J Trauma Acute Care Surg. 2013;75:961-7.

31. Cardenas JC, Matijevic N, Baer LA, Holcomb JB, Cotton BA, Wade CE. Elevated tissue plasminogen activator and reduced plasminogen activator inhibitor promote hyperfibrinolysis in trauma patients. Shock. 2014;41(6):514-21.

32. Ives $\mathrm{C}$, Inaba K, Branco BC, Okoye O, Schochl H, et al. Hyperfibrinolysis elicited via thromboelastography predicts mortality in trauma. JAm Coll Surg. 2012;215:496-502.

33. Roberts I, Shakur H, Afolabi A, et al. for the CRASH-2 collaborators. The importance of early treatment with tranexamic acid in bleeding trauma patients: an exploratory analysis of the CRASH-2 randomised controlled trial. Lancet. 2011;377:1096-101.
34. S-3-Leitlinie "Polytrauma/Schwerverletzten-Behandlung" der Deutschen Gesellschaft für Unfallchirurgie - AWMF Register-Nr. 012/019Stand 07/2011.

35. Schöchl H, Frietsch T, Pavelka M, Jámbor C. Hyperfibrinolysis after major trauma: differential diagnosis of lysis patterns and prognostic value of thrombelastometry. JTrauma. 2009;67:125-31.

36. Bundesärztekammer (BÄK). Querschnitts-Leitlinien (BÄK) zur Therapie mit Blutkomponenten und Plasmaderivaten. 4. überarb. und aktual. Auflage 2014. http:// www.bundesaerztekammer.de/fileadmin/user_upload/ downloads/QLL_Haemotherapie_2014.pdf. Accessed February 1,2015.

37. Fries D, Gütl M, Hofmann N, Innerhofer P, Kozek S. et al. ÖGARI Sektion Intensivmedizin. Gerinnungsmanagement in der Intensivmedizin 2012. http://www.oegari.at/web_ files/dateiarchiv/editor/im_gerinnungsmanagement_in_ der_intensivmedizin_2012_2.pdf. Accessed December 4, 2014.

38. Napolitano LM, Cohen MJ, Cotton BA, Schreiber MA, Moore EE. Tranexamic acid in trauma: How should we use it? J Trauma Acute Care Surg. 2013;74:1575-86.

39. Abdul-Kadir R, McLintock C, Ducloy AS, El-Refaey H, England $\mathrm{A}$, et al. Evaluation and management of postpartum hemorrhage: consensus from an international expert panel. Transfusion. 2014;54:1756-68.

40. Ducloy-Bouthors AS, Jude B, Duhamel A, et al. Highdose tranexamic acid reduces blood loss in postpartum haemorrhage. CritCare. 2011;15:R117.

41. Yang H, Zheng S, Shi C. Clinical study on the efficacy of tranexamic acid in reducing postpartum blood lose: a randomized, comparative, multicenter trial. Zhonghua Fu Chan KeZaZhi. 2001;36:590-2.

42. Gungorduk K, Asıcıoğlu O, Yıldırım G, Ark C, Tekirdağ Aİ, Besımoglu B. Can intravenous injection of tranexamic acid be used in routine practice with active management of the third stage of labor in vaginal delivery? A randomized controlled study. Am J Perinatol. 2013;30:407-13.

43. Bouet PE, Ruiz V, Legendre G, Gillard P, Descamps P, Sentilhes L. Policy of high-dose tranexamic acid for treating postpartum hemorrhage after vaginal delivery. J Matern Fetal Neonatal Med. 2015;29(10):1617-22. doi:10.3109/ 14767058.2015.1056731.

44. Goswami U, Sarangi S, Gupta S, Babbar S. Comparative evaluation of two doses of tranexamic acid used prophylactically in anemic parturients for lower segment cesarean section: a double-blind randomized case control prospective trial. Saudi J Anaesth. 2013;7:427-31.

45. Gai MY, Wu LF, Su QF, Tatsumoto K. Clinical observation of blood loss reduced by tranexamic acid during and after caesarean section: a multi-center, randomized trial. Eur J Obstet Gynecol Reprod Biol. 2004;112:154-7.

46. Abdel-Aleem H, Alhusaini TK, Abdel-Aleem MA, Menoufy M, Gülmezoglu AM. Effectiveness of tranexamic acid on blood loss in patients undergoing elective cesarean section: randomized clinical trial. J Matern Fetal Neonatal Med. 2013;26(17):1705-9.

47. Sekhavat L, Tabatabaii A, Dalili M, Farajkhoda T, Tafti AD. Efficacy of tranexamic acid in reducing blood loss after cesarean section. J Matern Fetal Neonatal Med. 2009;22:72-5.

48. Halder S, Samanta B, Sardar R, Chattopadhyay S. Tranexamic acid used before caesarean section reduces blood loss based on pre- and postoperative haemoglobin level: a casecontrol study. J Indian Med Assoc. 2013;111:184-6. 
49. Movafegh A, Eslamian L, Dorabadi A. Effect of intravenous tranexamic acidadministration on bloodloss during and aftercesarean delivery. Int JGynaecolObstet. 2011;115:224-6.

50. Sentürk MB, Cakmak Y, Yildiz G, Yildiz P. Tranexamic acid for cesarean section: a double-blind, placebo-controlled, randomized clinical trial. Arch Gynecol Obstet. 2013;287:641-5.

51. Xu J, Gao W, Ju Y. Tranexamic acid for the prevention of postpartum hemorrhage after cesarean section: a double-blind randomization trial. Arch Gynecol Obstet. 2013;287:463-8.

52. Gohel M, Patel P, Gupta A, Desai P. Efficacy of tranexamic acid in decreasing blood loss during and after cesarean section: a randomized case controlled prospective study. J Obstet Gynaecol India. 2007;57:227-30.

53. Shahid A, Khan A. Tranexamic acid in decreasing blood loss during and after caesarean section. J Coll Physicians Surg Pak. 2013;23:459-62.

54. Gungorduk K, Yildirim G, Asicioglu O, Gungorduk OC, Sudolmus S, Ark C. Efficacy of intravenous tranexamic acid in reducing blood loss after elective cesarean section: a prospective, randomized, double-blind, placebocontrolled study. Am J Perinatol. 2011;28:233-40.

55. Novikova N, Hofmeyr GJ. Tranexamic acid for preventing postpartum haemorrhage. Cochrane Database Syst Rev. 2010; . doi:10.1002/14651858.cd007872.pub2.

56. Heesen M, Böhmer J, Klöhr S, Rossaint R, van de Velde M, et al. Prophylactic tranexamic acid in parturients at low risk for post-partum haemorrhage: systematic review and meta-analysis. Acta Anaesthesiol Scand. 2014;58:1075-85.

57. Wang HY, Hong SK, Duan Y, Yin HM. Tranexamic acid and blood loss during and after cesarean section: a metaanalysis. J Perinatol. 2015;35(10):818-25.

58. Girard T, Mörtl M, Schlembach D. New approaches to obstetric hemorrhage: the postpartum hemorrhage consensus algorithm. Curr Opin Anaesthesiol. 2014;27:267-267.

59. Halimeh S. Menorrhagia and bleeding disorders in adolescent females. Hamostaseologie. 2012;32:45-50.

60. Lóppez JA, Andrews RK, Afshar-Kharghan V, Berndt MC. Bernard Soulier syndrome. Blood. 1998;91:4397-418.

61. George JN, Caen JP, Nurden AT. Glanzmann's thrombasthenia: the spectrum of clinical disease. Blood. 1990;75:1383-95.

62. James AH. More than menorrhagia: a review of the obstetric and gynaecological manifestations of bleeding disorders. Haemophilia. 2005;11:295-307.

63. Lethhaby A, Farquhar C, Cook I. Antifibrinolytics for heavy menstrual bleeding. Cochrane Database Syst Rev. 2000; doi:10.1002/14651858.cd000249.

64. Chi C, Pollard D, Tuddenham EG, et al. Menorrhagia in adolescents with inherited bleeding disorders. J Pediatr Adolesc Gynecol. 2010;23:215-22.

65. Mohri H. High dose of tranexamic acid for treatment of severe menorrhagia in patients with von Willebrand disease. JThromb Thrombolysis. 2002;14:255-7.

66. Lumsden MA, Wedisinghe L. Tranexamic acid therapy for heavy menstrual bleeding. Expert Opin Pharmacother. 2011;12:2089-95.

67. Keeling D, Tait C, Makris M. Guideline on the selection and use of therapeutic products to treat haemophilia and other hereditary bleeding disorders. A United Kingdom Haemophilia Center Doctors' Organisation (UKHCDO) guideline approved by the British Committee for Standards in Haematology. Haemophilia. 2008;14:671-84.

68. Hernandez-Navarro F, Quintana M, Jimenez-Yuste V, Alvarez MT, Fernandez-Morata R. Clinical efficacy in bleeding and surgery in von Willebrand patients treated with Fanhdi a highly purified, doubly inactivated FVIII/VWF concentrate. Haemophilia. 2008;14:963-1967.

69. Hennewig U, Laws HJ, Eisert S, Gobel U. Bleeding and surgery in children with Glanzmann thrombasthenia with and without the use of recombinant factor VII a. Klin Padiatr. 2005;217:365-70.

70. Mannucci PM. Treatment of von Willebrand's Disease. NEngl J Med. 2004;351:683-94.

71. Morimoto Y, Yoshioka A, Sugimoto M, Imai Y, Kirita T. Haemostatic management of intraoral bleeding in patients with von Willebrand disease. Oral Dis. 2005;11:243-8.

72. Gluud LL, Klingenberg SL, Langholz SE. Systematic review: tranexamic acid for upper gastrointestinal bleeding. Aliment Pharmacol Ther. 2008;27:752-8.

73. HenryDA, O'ConnellDL. Effects of fibrinolyticinhibitors on mortality from upper gastrointestinal haemorrhage. BMJ. 1989;298:1142-6.

74. Bennett C, Klingenberg SL, Langholz E, Gluud LL. Tranexamic acid for upper gastrointestinal bleeding. Cochrane Database Syst Rev. 2014; . doi:10.1002/14651858.cd006640. pub3.

75. Zufferey P, Merquiol F, Laporte S, Decousus H, Mismetti P, et al. Do antifibrinolytics reduce allogeneic blood transfusion in orthopedic surgery? Anesthesiology. 2006;105:1034-46.

76. Kagoma YK, Crowther MA, Douketis J, Bhandari M, Eikelboom J, Lim W. Use of antifibrinolytic therapy to reduce transfusion in patients undergoing orthopedic surgery: a systematic review of randomized trials. Thromb Res. 2009;123:687-96.

77. Sukeik M, Alshryda S, Haddad FS, Mason JM. Systematic review and meta-analysis of the use of tranexamic acid in total hip replacement. J Bone Joint Surg Br. 2011;93:39-46.

78. Cid J,Lozano M. Tranexamic acid reduces allogeneic red cell transfusionsin patientsundergoing total kneearthroplasty: results of a meta-analysis of randomized controlled trials. Transfusion. 2005;45:1302-7.

79. Poeran J, Rasul R, Suzuki S, Danninger T, Mazumdar M, et al. Tranexamic acid use and postoperative outcomes in patients undergoing total hip or knee arthroplasty in the United States: retrospective analysis of effectiveness and safety. BMJ. 2014;349:g4829.

80. Huang F, Wu D, Ma G, Yin Z, Wang Q. The use of tranexamic acid to reduce blood loss and transfusion in major orthopedic surgery: a meta-analysis. J Surg Res. 2014;186:318-27.

81. Bidolegui F, Arce G, Lugones A, Pereira S, Vindver G. Tranexamic acid reduces blood loss and transfusion in patients undergoing total knee arthroplasty without tourniquet: a prospective randomized controlled trial. Open Orthop J. 2014;8:250-4.

82. Blanié A, Bellamy L, Rhayem Y, Flaujac C, Samama CM, Fontenay M, Rosencher N. Duration of postoperative fibrinolysis after total hip or knee replacement: a laboratory follow-up study. Thromb Res. 2013;131:e6-e11.

83. Zohar E, Ellis M, Ifrach N, Stern A, Sapir O, Fredman B. The postoperative blood-sparing efficacy of oral versus intravenous tranexamic acid after total knee replacement. Anesth Analg. 2004;99:1679-83.

84. Sadeghi M, Mehr-Aein A. Does a single bolus dose of tranexamic acid reduce blood loss and transfusion requirements during hip fracture surgery? A prospective randomized double blind study in 67 patients. Acta Med Iran. 2007;45:437-42.

85. Zufferey PJ, Miquet M, Quenet S, Martin P, Adam P, et al. Tranexamic acid in hip fracture surgery: a randomized controlled trial. BrJAnaesth. 2010;104:23-30. 
86. Narayan RK, Maas AI, Marshall LF, Servadei F, Skolnick BE, et al. Recombinant factor VIIA in traumatic intracerebral hemorrhage: results of a dose-escalation clinical trial. Neurosurgery. 2008;62:776-86.

87. Liumbruno GM, Bennardello F, Lattanzio A, Piccoli P, Rossetti G, Italian Society of Transfusion Medicine and Immunohaematology (SIMTI) Working Party. Recommendations for the transfusion management of patients in the peri-operative period. I. The pre-operative period. Blood Transfus. 2011;9:19-40.

88. Koster A, Börgermann J, Zittermann A, Lueth JU, GillisJanuszewski T, Schirmer U. Moderate dosage of tranexamic acid during cardiac surgery with cardiopulmonary bypass and convulsive seizures: incidence and clinical outcome. Br JAnaesth. 2013;110:34-40.

89. Dunning J, Versteegh M, Fabbri A, et al. Guideline on antiplatelet and anticoagulation management in cardiac surgery. Eur J Cardiothorac Surg. 2008;34:73-92.

90. Maddali MM, Rajakumar MC. Tranexamic acid and primary coronary artery bypass surgery: a prospective study. Asian Cardiovasc ThoracAnn. 2007;15:313-9.

91. Ngaage DL, Bland JM. Lessons from aprotinin: is theroutine use and inconsistent dosing of tranexamic acid prudent? Meta-analysis of randomised and large matched observational studies. Eur J Cardiothorac Surg. 2010;37:1375-83.

92. Sigaut S, Tremey B, Ouattara A, Couturier R, Taberlet C, et al. Comparison of two doses of tranexamic acid in adults undergoing cardiac surgery with cardiopulmonary bypass. Anesthesiology. 2014;120:590-600.

93. Molenaar IQ, Warnaar N, Groen H, Tenvergert EM, Slooff MJ, Porte RJ. Efficacy and safety of antifibrinolytic drugs in liver transplantation: a systematic review and metaanalysis. AmJ Transplant. 2007;7:185-94.

94. Henry DA, Carless PA, Moxey AJ, et al. Anti-fibrinolytic use for minimising perioperative allogeneic blood transfusion. Cochrane Database Syst Rev. 2011; . doi:10.1002/14651858. cd001886.

95. Wu CC, Ho W-M, Cheng S-B, Yeh DC, Wen MC, et al. Perioperative parenteral tranexamic acid in liver tumor resection: a prospective randomized trial toward "blood transfusion"free hepatectomy. Ann Surg. 2006;243:173-80.

96. Gurusamy KS, Li J, Sharma D, Davidson BR. Pharmacological interventions to decrease blood loss and blood transfusion requirements for liver resection. Cochrane Database Syst Rev. 2009;4:CD008085.

97. Crescenti A, Borghi G, Bignami E, Bertarelli G, Landoni $\mathrm{G}$, et al. Intraoperative use of tranexamic acid to reduce transfusion rate in patients undergoing radical retropubic prostatectomy: double blind, randomised, placebo controlled trial. BMJ.2011;343:d5701.

98. Hedlund PO. Antifibrinolytic therapy with Cyklokapron in connection with prostatectomy: a double blind study. Scand J Urol Nephrol. 1969;3:177-82.

99. Kaufmann J, Siefker K. Reduction of post-prostatectomy bleeding by medication (experience with the antifibrinolytic agent AMCA). Urologe. 1969;8:57-9.

100. Lundvall F, Nielsen NC. The hemostatic effect of tranexamic acid in conisatio colli uteri. Acta Obstet Gynecol Scand. 1984;63:81-4

101. Celebi N, Celebioglu B, Selcuk M, Canbay O, Karagoz AH, Aypar U. The role of antifibrinolytic agents in gynecologic cancer surgery. Saudi Med J.2006;27:637-41.

102. Caglar GS, Tasci Y, Kayikcioglu F, Haberal A. Intravenous tranexamic acid use in myomectomy: a prospective randomized double-blind placebo controlled study. Eur J Obstet Gynecol Reprod Biol. 2008;137:227-31.
103. Tzortzopoulou A, Cepeda MS, Schumann R, Carr DB. Antifibrinolytic agents for reducing blood loss in scoliosis surgery in children. Cochrane Database Syst Rev. 2008; . doi:10.1002/14651858.cd006883.pub2.

104. Schouten ES, van de Pol AC, Schouten AN, Turner NM, Jansen NJ, Bollen CW. The effect of aprotinin, tranexamic acid, and aminocaproic acid on blood loss and use of blood products in major pediatric surgery: a meta-analysis. Pediatr CritCare Med. 2009;10:182-90.

105. Goobie SM, Meier PM, Pereira LM, et al. Efficacy of tranexamic acid in pediatric craniosynostosis surgery: a double-blind, placebo-controlled trial. Anesthesiology. 2011;114:862-71.

106. Chauhan S, Bisoi A, Kumar N, et al. Dose comparison of tranexamic acid in pediatric cardiac surgery. Asian Cardiovasc Thorac Ann. 2004;12:121-4.

107. Grassin-Delyle S, Couturier R, Abe E, Alvarez JC, Devillier P, Urien S. A practical tranexamic acid dosing scheme based on population pharmacokinetics in children undergoing cardiac surgery. Anesthesiology. 2013;118:853-62.

108. Streif W, Knöfler R, Eberl W, Andres O, Bakchoul T, et al. Therapie hereditärer Thrombozytopathien Interdisziplinäre S2K-Leitlinie der Ständigen Kommission Pädiatrie der Gesellschaft für Thrombose- und Hämostaseforschung e. V.Hamostaseologie. 2014;34:269-75.

109. Leitlinie Thrombozytopathien Therapie AWMF Register Nr. 086-004, Klasse:S2K ICD10 Code Thrombozytopathie D69.1V2.4_28.04.2014.

110. Zahed R, Moharamzadeh P, Alizadeharasi S, Ghasemi A, Saeedi M. A new and rapid method for epistaxis treatment using injectable form of tranexamic acid topically: a randomized controlled trial. Am J Emerg Med. 2013;31:1389-92.

111. ATERO Study Group, Gaillard S, Dupuis-Girod S, Boutitie F, Rivière $S$, Morinière $S$, et al. Tranexamic acid for epistaxis in hereditary hemorrhagic telangiectasia patients: a European cross-over controlled trial in a rare disease. J Thromb Haemost. 2014;12:1494-502.

112. Chan CC, Chan YY, Tanweer F. Systematic review and metaanalysis of the use of tranexamic acid in tonsillectomy. Eur Arch Otorhinolaryngol. 2013;270:735-48.

113. Hillman J, Fridriksson S, Nilsson O, Yu Z, Saveland H, Jakobsson KE. Immediate administration of tranexamic acid and reduced incidence of early rebleeding after aneurysmal subarachnoid hemorrhage: a prospective randomized study. J Neurosurg. 2002;97:771-8.

114. Palmer JD, Francis JL, Pickard JD, Iannotti F. The efficacy and safety of aprotinin for hemostasis during intracranial surgery. J Neurosurg. 2003;98:1208-16.

115. Baharoglu MI, Germans MR, Rinkel GJ, Algra A, Vermeulen $\mathrm{M}$, et al. Antifibrinolytic therapy for aneurysmal subarachnoid haemorrhage. Cochrane Database Syst Rev. 2013; . doi:10.1002/14651858.cd001245.pub2.

116. European Stroke Organization, Steiner T, Juvela S, Unterberg A, Jung C, Forsting M, Rinkel G. European Stroke Organizationguidelinesfor themanagementofintracranial aneurysms and subarachnoid haemorrhage. Cerebrovasc Dis. 2013;35:93-112.

117. Steinmetz H, Berkefeld J, Forsting M. et al. Aneurysmale Subarachnoidalblutung. In: Leitlinien für Diagnostik und Therapie in der Neurologie, 4th edn. Thieme: Stuttgart; 2008. p. 654.

118. Steinmetz H, Berkefeld J, Forsting M. et al. Subarachnoidalblutung (SAB). In: Diener HC, Weimar C, Kommission "Leitlinien" der Deutschen Gesellschaft für Neurologie, editors. Leitlinien für Diagnostik und Therapie in der Neu- 
rologie, 5th edn. Stuttgart: Thieme; 2012. http://www. awmf.org/leitlinien/detail/ll/030-073.html.

119. CRASH-2 Collaborators, Intracranial Bleeding Study. Effect of tranexamic acid in traumatic brain injury: a nested randomised, placebo controlled trial (CRASH-2 Intracranial Bleeding Study). BMJ. 2011;343:d3795.

120. Germans MR, Post R, Coert BA, Rinkel GJ, Vandertop WP, Verbaan D. Ultra-early tranexamic acid after subarachnoid hemorrhage (ULTRA): study protocol for a randomized controlled trial. Trials. 2013;14:143.
121. Meretoja A, Churilov L, Campbell BC, Aviv RI, Yassi N, et al. The spot sign and tranexamic acid on preventing ICH growth - AUStralasia Trial (STOP-AUST): protocol of a phase II randomized, placebo-controlled, double-blind, multicenter trial. Int J Stroke. 2014;9:519-24.

122. Dewan Y, Komolafe EO, Mejía-Mantilla JH, Perel P, Roberts I, Shakur H, CRASH-3 Collaborators. CRASH-3 - tranexamic acid for the treatment of significant traumatic brain injury: study protocol for an international randomized, doubleblind, placebo-controlled trial. Trials. 2012;13:87. 